\title{
The health status of the early care and education workforce in the USA: a scoping review of the evidence and current practice
}

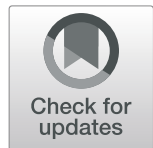

\author{
Laura M. Lessard ${ }^{1 *}$, Katilyn Wilkins ${ }^{2}$, Jessica Rose-Malm² and M. Chaplin Mazzocchi ${ }^{1}$
}

\author{
* Correspondence: LLessard@udel. \\ edu \\ ${ }^{1}$ University of Delaware, College of \\ Health Sciences, Newark, DE 19716, \\ USA \\ Full list of author information is \\ available at the end of the article
}

\begin{abstract}
Background: More than two million early care and education (ECE) providers care for young children in the USA each day. These providers tend to earn low wages and many are enrolled in public assistance programs. Nearly all ECE providers are female and they are disproportionately women of color. Despite the fact that these attributes place the ECE workforce at greater risk of chronic disease, the health status of the workforce is not established and the availability and effectiveness of interventions to improve their health status is also not known.

Methods: We conducted a scoping review of both the published literature and current practice to identify all articles and interventions targeting the health status of the ECE workforce. Our search strategy identified scientific articles published in English within the past 10 years as well as any interventions targeting the ECE workforce that have been implemented within the past 3 years. Data from both scientific articles and practice were extracted using systematic methods and summarized.
\end{abstract}

Results: Thirteen studies described some component of physical health including diet quality (11 studies), physical activity (8 studies), and height/weight/body mass index (7 studies), and 21 studies assessed component(s) of mental health including depression (15 studies), stress (8 studies), and mindfulness (3 studies). ECE providers reported a high prevalence of overweight, obesity, and chronic disease diagnoses and spend significant time being sedentary, and some report low diet quality. Mental health concerns in this population include depression and high stress. Eleven interventions targeting ECE workforce wellness were also identified; most focused on nutrition, physical activity and/ or stress.

Conclusion: The limited evidence available for review describes a workforce in need of health promotion interventions to address high levels of mental and physical health challenges, some above and beyond peers with comparable demographic characteristics. Several promising interventions were identified from both the published and unpublished literature; these interventions should be further implemented and evaluated to assess their impact on the workforce.

Keywords: Child care, Worker health, Health promotion

\section{Background}

In the United States (USA), more than two million early care and education (ECE) providers care for approximately ten million young children every day [1]. The ECE

(c) The Author(s). 2020 Open Access This article is distributed under the terms of the Creative Commons Attribution 4.0 International License (http://creativecommons.org/licenses/by/4.0/), which permits unrestricted use, distribution, and reproduction in any medium, provided you give appropriate credit to the original author(s) and the source, provide a link to the Creative Commons license, and indicate if changes were made. The Creative Commons Public Domain Dedication waiver (http://creativecommons.org/ publicdomain/zero/1.0/) applies to the data made available in this article, unless otherwise stated. 
system in the USA serves children from birth through 6 years of age and includes several program types: child care centers that can be for-profit or non-profit, Early Head Start and Head Start Programs that are funded through grants from the federal government to serve children from low-income households, pre-kindergarten programs available in some jurisdictions for children age 3-4 years and family child care programs where a small number of children receive care from one or more adults in a home setting [2]. The ECE workforce that supports this system is comprised of populations that are considered higher risk for chronic disease. ECE providers tend to earn low wages (\$11.17/h versus $\$ 18.50 / \mathrm{h}$ for all occupations), and more than half of all ECE providers are enrolled in at least one public support program, such as Medicaid or Supplemental Nutrition Assistance. Nearly all ECE providers are female and they are disproportionately women of color [3] (see Table 1 for more demographic characteristics of the ECE workforce in the USA).

Just 15\% of the ECE workforce receives employer-sponsored health insurance, compared to $49.9 \%$ of workers in other occupations [3]. According to the Early Childhood Workforce Index, in 2012, prior to the full implementation of the Affordable Care Act (ACA), nearly $25 \%$ of center-based staff, and $21-28 \%$ of home-based providers were uninsured. A few studies conducted after Medicaid (publicly funded health insurance) expansion have shown that more ECE providers are enrolling in Medicaid as it is made

Table 1 Demographic characteristics of child care workers in the USA, 2014

\begin{tabular}{|c|c|c|}
\hline & Child care workers & All other workers \\
\hline \multicolumn{3}{|l|}{ Gender } \\
\hline Men & $4.4 \%$ & $53.7 \%$ \\
\hline Women & $95.6 \%$ & $46.3 \%$ \\
\hline \multicolumn{3}{|l|}{ Citizenship status } \\
\hline US born & $81.2 \%$ & $83.5 \%$ \\
\hline Naturalized US citizen & $8.3 \%$ & $7.8 \%$ \\
\hline Non-naturalized immigrant & $10.5 \%$ & $8.7 \%$ \\
\hline \multicolumn{3}{|l|}{ Race/ethnicity* } \\
\hline White & $60.1 \%$ & $66.1 \%$ \\
\hline Black & $14.1 \%$ & $10.6 \%$ \\
\hline Hispanic & $19.8 \%$ & $15.7 \%$ \\
\hline Asian & $3.9 \%$ & $5.8 \%$ \\
\hline Other & $2.1 \%$ & $1.9 \%$ \\
\hline \multicolumn{3}{|l|}{ Education } \\
\hline Less than high school & $8.6 \%$ & $8.0 \%$ \\
\hline High school & $30.5 \%$ & $27.2 \%$ \\
\hline Some college & $39.4 \%$ & $29.7 \%$ \\
\hline Bachelor's degree & $17.7 \%$ & $22.8 \%$ \\
\hline Advanced degree & $3.8 \%$ & $12.4 \%$ \\
\hline \multicolumn{3}{|l|}{ Age } \\
\hline $18-22$ & $15.4 \%$ & $7.3 \%$ \\
\hline $23-49$ & $55.7 \%$ & $59.1 \%$ \\
\hline $50+$ & $29.0 \%$ & $33.7 \%$ \\
\hline
\end{tabular}

*Race/ethnicity categories are mutually exclusive (i.e., white non-Hispanic, black non-Hispanic, and Hispanic any race) Adapted with permission from Economic Policy Institute [3] 
available in their states [1]. However, given that only 33 states have expanded Medicaid coverage and lack of publicly available data, it is difficult to get the full picture of health insurance coverage for this population [1]. Health disparities and increased chronic disease risk among people with low socioeconomic status, racial minorities and the uninsured is well-documented [4-6]. Despite a potentially elevated risk for chronic disease, little research has been done on the health of the ECE workforce or on the effectiveness of non-clinical health interventions that may reduce chronic disease risk within this population.

Worksite wellness programs are growing in popularity as a way to improve employee productivity, retention, and job satisfaction and lower healthcare costs [7]. These programs typically focus on modifiable health behaviors such as smoking, diet, physical activity, and receiving cardiovascular disease screenings. However, worksite wellness programs are not widely available to the ECE workforce $[8,9]$. Most ECE settings operate independently or within small organizations that may not have the resources to offer worksite wellness programs. One exception is ECE settings that are embedded within larger organizations (e.g., large companies, universities, government settings) where the ECE workforce has access to wellness programs offered organization-wide.

The purpose of this project was to establish the current state of the science with regards to ECE workforce health status as well as begin to understand the current state of practice.

\section{Methods}

We used a scoping review approach to collect and describe this emerging field $[10,11]$. This approach allows for a more flexible integration of different types of evidence, as is appropriate for a new field. We compiled both published, peerreviewed evidence, and information on unpublished interventions and programs in an effort to identify what is currently known about the health status of the ECE workforce and examples of interventions currently being implemented to improve health status.

\section{Data sources}

We used two different procedures to gather data for this scoping review, one focused on the published literature and another on practice. For the published literature, we first searched both PubMed and Google Scholar. Search terms encapsulated the environment (child care or daycare or early care and education or preschool or head start), the target population (workforce or employee or worksite or teacher or provider) and at least one component of health (health or wellness or stress or well-being). We also conducted hand searches of the reference sections of relevant papers and forward citation searches.

For practice, we disseminated a call for interventions via several different professional channels focused on the ECE workforce in the USA (e.g., Child Care Aware of America, the CDC's Division of Nutrition, Physical Activity and Obesity's Early Care and Education News Blast, Nemours Children's Health System). In addition, the authors reached out directly to individuals and organizations to inquire about any relevant programs. 


\section{Study selection}

Following the searches, a multi-step review process was used to select publications to include in the review. For the published literature, inclusion criteria consisted of both descriptive and intervention studies focusing on the target population (ECE workforce in the USA), published in English within the past 10 years. We did not limit the types of study designs that were included in this review and so we did not assess the quality of the resulting evidence. Given the relatively small size of the evidence base in this area, we included otherwise unpublished dissertations, Master's theses and organizational reports (e.g., government, non-profit). To assess whether articles met these criteria, titles and abstracts were first reviewed by the first author for relevance and duplicates were deleted. Next, full-text of remaining papers $(n=43)$ were reviewed to confirm that each paper met the inclusion criteria. Lastly, discussion with the whole author team was used if there was ambiguity about a particular paper. During this process, six articles were excluded because they were conducted outside of the USA and two were excluded because they were commentary pieces and did not contain primary data.

For programs, we included any program targeting some component of ECE workforce health that has been offered in the USA at least one time within the past 3 years. We excluded studies and programs that focused on only acute health topics (e.g., infectious disease or injuries). Both published intervention studies and unpublished programs were included.

\section{Data extraction}

For publications, data on target population/sample, methods, and results were gathered from the full-text of the articles. One author (MM) did an initial extraction of each article which was reviewed and confirmed by the lead author to confirm the accuracy of the extraction and summarization. Following extraction, we summarized the resulting evidence qualitatively and present themes across the evidence base. Only quantitative data on health status or behaviors was included (e.g., attitudinal or knowledge data were excluded from extraction).

For practice, organizations and individuals were asked to complete a form providing information about the intervention design (e.g., target behaviors/outcomes; activities or program components) and any evaluation data or results. We followed up with individuals as needed to obtain complete information.

\section{Results}

In total, 26 articles met the inclusion criteria for health status (Table 2). Two articles were excluded from the health status analysis because they involved qualitative methods and did not present prevalence estimates [36, 37]. The themes from these papers were, however, integrated within the results section.

\section{Physical health}

Thirteen studies described some component of physical health including diet quality (11 studies), physical activity (8 studies), and height/weight/BMI (7 studies). Five studies each measured sleep and smoking and four studies measured chronic disease status. 
Table 2 Summary of research articles describing the health status of the early care and education workforce identified in a scoping review

\begin{tabular}{|c|c|c|c|}
\hline $\begin{array}{l}\text { Source } \\
\text { (author, year) } \\
\end{array}$ & Target population $(n)$ & Methods & $\begin{array}{l}\text { Health outcome(s) } \\
\text { (measurement tool) }\end{array}$ \\
\hline $\begin{array}{l}\text { Becker et al., } \\
2017 \text { [12] }\end{array}$ & $\begin{array}{l}\text { HS teachers }(n=1001) \\
\text { in Pennsylvania }\end{array}$ & $\begin{array}{l}\text { Web-based survey of HS } \\
\text { teachers in } 37 \text { Pennsylvania } \\
\text { HS Programs. }\end{array}$ & $\begin{array}{l}\text { - Depression (CES-D) } \\
\text { - Dispositional Mindfulness } \\
\text { (CAMS-R) } \\
\text { - Workplace stress (JCQ) }\end{array}$ \\
\hline $\begin{array}{l}\text { Denham et al., } \\
2017 \text { [13] }\end{array}$ & $\begin{array}{l}\text { Female lead teachers } \\
\text { from both CCC and HS } \\
(n=127) \text { in a Mid Atlantic } \\
\text { USA city }\end{array}$ & $\begin{array}{l}\text { Web-based survey of female } \\
\text { lead teachers at for-profit, } \\
\text { faith-based, and university } \\
\text { child care work settings, as } \\
\text { well as HS programs. }\end{array}$ & $\begin{array}{l}\text { - Child Care Worker Job Stress } \\
\text { (CCW-JSI) }\end{array}$ \\
\hline $\begin{array}{l}\text { Figueroa and } \\
\text { Wiley, } 2016 \\
{[14]}\end{array}$ & $\begin{array}{l}\text { FCC providers }(n=107) \\
\text { in a Midwestern USA city }\end{array}$ & $\begin{array}{l}\text { Web-based or paper survey } \\
\text { of licensed FCC providers } \\
\text { recruited through local child } \\
\text { care resource and referral } \\
\text { agencies. }\end{array}$ & $\begin{array}{l}\text { - Physical Activity (Go NAP } \\
\text { SACC Physical Activity } \\
\text { Self-Assessment) }\end{array}$ \\
\hline $\begin{array}{l}\text { Grant et al., } \\
2016[15]\end{array}$ & $\begin{array}{l}\text { CCC teachers }(n=1129) \\
\text { from all } 50 \text { states and } \\
\text { Washington, DC }\end{array}$ & $\begin{array}{l}\text { Paper survey of teachers from } \\
\text { a national sample of ECE } \\
\text { programs. }\end{array}$ & $\begin{array}{l}\text { - General Stress (Perceived } \\
\text { Stress Scale) } \\
\text { - Job-relate emotional } \\
\text { exhaustion }\end{array}$ \\
\hline $\begin{array}{l}\text { Halloran et al., } \\
2018 \text { [16] }\end{array}$ & $\begin{array}{l}\text { HS teachers }(n=85) \text { in } \\
\text { Rhode Island }\end{array}$ & $\begin{array}{l}\text { Paper survey of HS teachers } \\
\text { from } 22 \text { HS centers in Rhode } \\
\text { Island. }\end{array}$ & $\begin{array}{l}\text { - Fruit and vegetable intake } \\
\text { (FVS) }\end{array}$ \\
\hline $\begin{array}{l}\text { Hibbs-Ship et al., } \\
2015 \text { [17] }\end{array}$ & $\begin{array}{l}\text { HS staff }(n=154) \text { in } \\
\text { Colorado }\end{array}$ & $\begin{array}{l}\text { Paper surveys of teaching, } \\
\text { administrative, program, } \\
\text { foodservice, and } \\
\text { transportation staff at HS } \\
\text { locations. } 25 \text { completed } \\
\text { additional individual } \\
\text { telephone interviews. }\end{array}$ & $\begin{array}{l}\text { - Physical activity } \\
\text { - Diet } \\
\text { - Barriers to exercise } \\
\text { - Self-report of healthy } \\
\text { lifestyle }\end{array}$ \\
\hline $\begin{array}{l}\text { Hindman and } \\
\text { Bustamante, } \\
2019 \text { [18] }\end{array}$ & $\begin{array}{l}\text { HS teachers }(n=362) \text { in } \\
\text { all } 50 \text { states and } \\
\text { Washington, DC }\end{array}$ & $\begin{array}{l}\text { Paper survey of HS teachers } \\
\text { conducted twice within the } \\
\text { same year, once in fall and } \\
\text { spring. }\end{array}$ & - Depression (CES-D) \\
\hline $\begin{array}{l}\text { Jennings, } \\
2015[19]\end{array}$ & $\begin{array}{l}\text { Teachers from both } \\
\text { CCC and HS }(n=35) \\
\text { in California }\end{array}$ & $\begin{array}{l}\text { Web-based survey and follow } \\
\text { up phone interview of } 21 \\
\text { teachers working in privately } \\
\text { funded independent } \\
\text { preschools and } 14 \mathrm{HS} \\
\text { teachers. }\end{array}$ & $\begin{array}{l}\text { - Depression (BDI) } \\
\text { - Burnout (MBI) } \\
\text { - Mindfulness (FFMQ) }\end{array}$ \\
\hline $\begin{array}{l}\text { Jeon et al., } \\
2018 \text { [20] }\end{array}$ & $\begin{array}{l}\text { Teachers from CCC } \\
(n=1129) \text { in all } 50 \\
\text { states }\end{array}$ & $\begin{array}{l}\text { Mailed survey of preschool } \\
\text { classroom teachers in CCC } \\
\text { and public pre-kindergarten } \\
\text { programs. }\end{array}$ & $\begin{array}{l}\text { - Depression (CES-D) } \\
\text { - Stress (Perceived Stress } \\
\text { Scale) }\end{array}$ \\
\hline $\begin{array}{l}\text { Jeon et al., } \\
2019[21]\end{array}$ & $\begin{array}{l}\text { Teachers from CCC } \\
(n=207) \text { in a Southern } \\
\text { state in the USA }\end{array}$ & Paper survey of CCC teachers. & $\begin{array}{l}\text { - Depression (RAND Health) } \\
\text { - Job-related stress (CCW-JSI) }\end{array}$ \\
\hline $\begin{array}{l}\text { Ling, } \\
2018 \text { [22] }\end{array}$ & $\begin{array}{l}\text { HS teachers }(n=80) \\
\text { in Michigan }\end{array}$ & $\begin{array}{l}\text { Web-based survey sent to } \\
\text { each HS center supervisor to } \\
\text { distribute to all HS teachers. }\end{array}$ & $\begin{array}{l}\text { - Physical Activity (IPAQ) } \\
\text { - Depression (RAND Health) } \\
\text { - Diet } \\
\text { - Quality of Life (SF-36) } \\
\text { - Self-reported height and } \\
\text { weight }\end{array}$ \\
\hline $\begin{array}{l}\text { Linnan et al., } \\
2017 \text { [23] }\end{array}$ & $\begin{array}{l}\text { Teachers and } \\
\text { administrators from } \\
\text { CCC }(n=674) \text { in } \\
\text { North Carolina }\end{array}$ & $\begin{array}{l}\text { Web-based and paper } \\
\text { surveys of } 118 \text { administrators } \\
\text { and } 556 \text { staff from } 74 \text { CCCs } \\
\text { in North Carolina. }\end{array}$ & $\begin{array}{l}\text { - Health behaviors (CHART) } \\
\text { - Dietary Intake (Dietary } \\
\text { Screener Questionnaire } \\
\text { and the Diet History } \\
\text { Questionnaire) } \\
\text { - Tobacco and E-Cigarette } \\
\text { (BRFSS) } \\
\text { - Sleep (PSQI) } \\
\text { - Depression (CES-D) }\end{array}$ \\
\hline
\end{tabular}


Table 2 Summary of research articles describing the health status of the early care and education workforce identified in a scoping review (Continued)

\begin{tabular}{|c|c|c|c|}
\hline $\begin{array}{l}\text { Source } \\
\text { (author, year) }\end{array}$ & Target population ( $n$ ) & Methods & $\begin{array}{l}\text { Health outcome(s) } \\
\text { (measurement tool) }\end{array}$ \\
\hline & & & $\begin{array}{l}\text { - Measured height, weight, } \\
\text { waist circumference, heart } \\
\text { rate, and blood pressure } \\
\text { - Physical activity ( } 1 \text { week of } \\
\text { accelerometer monitoring } \\
\text { using a GT3X ActiGraph } \\
\text { monitor) }\end{array}$ \\
\hline $\begin{array}{l}\text { Magerko, } \\
2016[24]\end{array}$ & $\begin{array}{l}\text { FCC providers ( } n=165 \\
\text { for survey) in Illinois }\end{array}$ & Survey of FCC providers. & $\begin{array}{l}\text { - Weight status (BRFSS) for } \\
\text { BMI } \\
\text { - Perceived stress (PSS-14) } \\
\text { - Smoking (WHO) } \\
\text { - Nutrition (BRFSS) } \\
\text { - Physical activity (GPAQ) } \\
\text { - Life satisfaction (BRFSS) } \\
\text { - Sleep (BRFSS) } \\
\text { - Chronic diseases (BRFSS) } \\
\text { - Depression (CES-D 20) }\end{array}$ \\
\hline $\begin{array}{l}\text { Magerko, } \\
2016[24]\end{array}$ & $\begin{array}{l}\text { FCC providers ( } n=67 \text { for } \\
\text { measurements) in Illinois }\end{array}$ & $\begin{array}{l}\text { Survey and measurements } \\
\text { of FCC providers. }\end{array}$ & $\begin{array}{l}\text { - Measured height and } \\
\text { weight } \\
\text { - Body composition } \\
\text { - Measured blood pressure } \\
\text { - Measured blood cholesterol } \\
\text { - Dietary intake ( } 24-h \text { recall) } \\
\text { - Physical activity ( } n=28 \\
\text { providers; accelerometer) } \\
\text { - Health behaviors (BRFSS) }\end{array}$ \\
\hline $\begin{array}{l}\text { Ota et al., } \\
2013[25]\end{array}$ & $\begin{array}{l}\text { Child care providers } \\
\text { from both CCC and FCC } \\
\text { homes }(n=39) \text { in Utah }\end{array}$ & $\begin{array}{l}\text { Survey of primary and } \\
\text { secondary caregivers from } \\
11 \text { family home providers, } \\
18 \text { family group providers, } \\
\text { and } 10 \text { CCC providers. }\end{array}$ & - Stress (PSI-SF) \\
\hline $\begin{array}{l}\text { Roberts et al., } \\
2017 \text { [26] }\end{array}$ & $\begin{array}{l}\text { Teachers from CCC } \\
(n=1640) \text { in one } \\
\text { Midwestern state in } \\
\text { the USA }\end{array}$ & $\begin{array}{l}\text { Paper surveys of educators } \\
\text { within } 1063 \text { schools or } \\
\text { centers. }\end{array}$ & $\begin{array}{l}\text { - Work related stress } \\
\text { (CCW-JSI) } \\
\text { - Depression (CESD-10) } \\
\text { - Health Insurance }\end{array}$ \\
\hline $\begin{array}{l}\text { Sandilos et al., } \\
2015 \text { [27] }\end{array}$ & $\begin{array}{l}\text { Teachers from both } \\
\text { CCC and HS }(n=59) \\
\text { in Northeastern and } \\
\text { Southeastern USA }\end{array}$ & $\begin{array}{l}\text { Paper survey of teachers } \\
\text { from } \mathrm{HS} \text { and preschool } \\
\text { centers serving children } \\
\text { who receive free or } \\
\text { reduced lunch. }\end{array}$ & $\begin{array}{l}\text { - Depression/Emotional } \\
\text { Health (Kessler } \\
\text { Psychological Distress Scale) } \\
\text { - Stress (Job Control portion } \\
\text { of CCW-JSI) }\end{array}$ \\
\hline $\begin{array}{l}\text { Sharma et al., } \\
2013 \text { [28] }\end{array}$ & $\begin{array}{l}\text { HS Teachers and teachers' } \\
\text { aides }(n=213) \text { in Texas }\end{array}$ & $\begin{array}{l}\text { Paper survey of HS teaching } \\
\text { staff (i.e., teachers and } \\
\text { teachers' aides). }\end{array}$ & $\begin{array}{l}\text { - Dietary behavior (semi- } \\
\text { quantitative food recall } \\
\text { questionnaire) } \\
\text { - Self-report height and } \\
\text { weight }\end{array}$ \\
\hline $\begin{array}{l}\text { Snyder and Hill, } \\
2018 \text { [29] }\end{array}$ & $\begin{array}{l}\text { HS teachers and other } \\
\text { staff }(n=312) \text { in Ohio }\end{array}$ & $\begin{array}{l}\text { Web-based survey of } \\
\text { teaching, family support, } \\
\text { health, administrative, and } \\
\text { support staff of the HS } \\
\text { agency. }\end{array}$ & $\begin{array}{l}\text { - Stress (PSS-4) } \\
\text { - Mindfulness (MAAS) } \\
\text { - Mental Health (NHANES } \\
\text { and BRFSS) } \\
\text { - Chronic conditions } \\
\text { (NHANES) } \\
\text { - Smoking (BRFSS) } \\
\text { - General Health Status (BRFSS) }\end{array}$ \\
\hline $\begin{array}{l}\text { Song et al., } \\
2016 \text { [30] }\end{array}$ & $\begin{array}{l}\text { HS teachers and other } \\
\text { staff who were aged } \\
18 \text { years or older } \\
(n=307) \text { in Michigan }\end{array}$ & $\begin{array}{l}\text { Web-based survey of } \\
\text { teachers and other staff } \\
\text { from } 17 \text { Michigan Migrant } \\
\text { and Seasonal HS centers. }\end{array}$ & $\begin{array}{l}\text { - Self-reported height and } \\
\text { weight } \\
\text { - Food security (US } \\
\text { household food security } \\
\text { survey module) }\end{array}$ \\
\hline $\begin{array}{l}\text { Swindle et al., } \\
2018 \text { [31] }\end{array}$ & $\begin{array}{l}\text { Early childhood educators } \\
(n=307) \text { in Arkansas }\end{array}$ & $\begin{array}{l}\text { Survey completed on } \\
\text { location or at a conference } \\
\text { for ECE providers. }\end{array}$ & $\begin{array}{l}\text { - Dietary intake (FMI) } \\
\text { - Food insecurity (Household } \\
\text { Food Security Survey) }\end{array}$ \\
\hline
\end{tabular}


Table 2 Summary of research articles describing the health status of the early care and education workforce identified in a scoping review (Continued)

\begin{tabular}{|c|c|c|c|}
\hline $\begin{array}{l}\text { Source } \\
\text { (author, year) }\end{array}$ & Target population $(n)$ & Methods & $\begin{array}{l}\text { Health outcome }(\mathrm{s}) \\
\text { (measurement tool) }\end{array}$ \\
\hline $\begin{array}{l}\text { Tovar et al., } \\
2017[32]\end{array}$ & $\begin{array}{l}\text { FCC providers }(n=166) \\
\text { in North Carolina }\end{array}$ & $\begin{array}{l}\text { Paper surveys completed by } \\
\text { providers at on-site visits. }\end{array}$ & $\begin{array}{l}\text { - Physical activity (BRFSS) } \\
\text { - Dietary intake (Brief Block } \\
\text { Food Frequency } \\
\text { Questionnaire) } \\
\text { - Sleep (Medical Outcomes } \\
\text { Study sleep scale) } \\
\text { - Stress (Perceived Stress } \\
\text { Scale) } \\
\text { - Measured height and weight }\end{array}$ \\
\hline $\begin{array}{l}\text { Ward et al., } \\
2018 \text { [9] }\end{array}$ & $\begin{array}{l}\text { CCC directors and } \\
\text { participating staff } \\
(n=553) \text { in } \\
\text { North Carolina }\end{array}$ & $\begin{array}{l}\text { A combination of an } \\
\text { objective physical activity } \\
\text { measure, physical } \\
\text { measurements, web-based } \\
\text { and paper-based surveys, and } \\
\text { an environmental } \\
\text { assessment. }\end{array}$ & $\begin{array}{l}\text { - Health behaviors (CHART) } \\
\text { - Smoking (BRFSS) } \\
\text { - Physical activity (7 days of } \\
\text { accelerometer wear) } \\
\text { - Dietary intake (Dietary } \\
\text { Screener Questionnaire } \\
\text { and the Diet History } \\
\text { Questionnaire) } \\
\text { - Sleep (Society for Behavioral } \\
\text { Medicine's Common Data } \\
\text { Elements and Pittsburgh } \\
\text { Sleep Quality Index) } \\
\text { - Depression (CESD) }\end{array}$ \\
\hline $\begin{array}{l}\text { Whitaker et al., } \\
2013 \text { [33] }\end{array}$ & $\begin{array}{l}\text { Female HS staff } \\
(n=2122) \text { in } \\
\text { Pennsylvania }\end{array}$ & $\begin{array}{l}\text { Web-based survey of } \\
\text { female HS program } \\
\text { directors, managers, } \\
\text { classroom teachers, } \\
\text { home-based visitors, } \\
\text { and family service } \\
\text { workers. Staff from } 66 \\
\text { Pennsylvania HS programs. }\end{array}$ & $\begin{array}{l}\text { - Depression (CES-D) } \\
\text { - Chronic disease diagnoses } \\
\text { (BRFSS, NHIS) } \\
\text { - Health-related quality of life } \\
\text { (NHIS and BRFSS) }\end{array}$ \\
\hline $\begin{array}{l}\text { Whitaker et al., } \\
2015 \text { [34] }\end{array}$ & $\begin{array}{l}\text { HS Teachers and } \\
\text { assistant teachers } \\
(n=1001) \text { in } \\
\text { Pennsylvania }\end{array}$ & $\begin{array}{l}\text { Web-based survey of } \\
\text { teachers and assistant } \\
\text { teachers from } 37 \mathrm{HS} \\
\text { programs in Pennsylvania. }\end{array}$ & $\begin{array}{l}\text { - Depression (CES-D) } \\
\text { - Financial well-being }\end{array}$ \\
\hline $\begin{array}{l}\text { Witherell, } \\
2013 \text { [35] }\end{array}$ & $\begin{array}{l}\text { CCC employees } \\
(n=101) \text { in } \\
\text { Michigan }\end{array}$ & $\begin{array}{l}\text { Paper survey of CCC head or } \\
\text { lead teachers, group leaders, } \\
\text { assistant teachers, and aides. }\end{array}$ & - Depression (CES-D; BSI) \\
\hline
\end{tabular}

FCC family child care, CCC child care centers, HS Head Start

\section{Diet quality}

Ten studies measured fruit and/or vegetable consumption. The proportion of providers meeting recommendations for fruit and vegetable consumption (3.5 cups or 5 servings per day) varied from $22.5 \%$ of Head Start staff [17] to $50 \%$ of family child care (FCC) providers [32]. Mean fruit and vegetable consumption exceeded recommendations in one study of Head Start teachers [16] but were below recommendations in one study of child care center (CCC) directors and staff [9].

\section{Physical activity}

Five studies explored the proportion of providers meeting national physical activity requirements (e.g., $150 \mathrm{~min}$ per week of moderate to vigorous physical activity); the results included $27 \%$ of CCC employees [23], 29.4\% of CCC directors and staff [9], and $55 \%$ of Head Start teachers [22] met these recommendations. Approximately 40-50\% of FCC providers in two studies reported meeting guidelines [24, 32]. Providers across 
four studies reported large quantities of sedentary time; one study of Head Start (HS) teachers found they spent $291.69 \mathrm{~min}(4.9 \mathrm{~h})$ per weekday sitting [22]; two studies of CCC employees found a mean of 481 and $513.6 \mathrm{~min}(8-8.6 \mathrm{~h})$ of sedentary time per day, respectively $[9,23]$. One study of FCC providers found that nearly one third (32.8\%) reported nine or more hours of sedentary time per day [24].

\section{Weight status}

Seven studies assessed height and weight and converted to BMI; high levels of overweight and obesity (defined as BMI $\geq 25$ ) were reported. Rates of overweight and obesity included between 73.5 and $80.1 \%$ for HS staff [22, 28, 30], 71\% and 89.9\% for FCC providers, and $88.5 \%$ and $87.2 \%$ of CCC staff $[9,23]$. Nationally, $71.6 \%$ of adults are overweight or obese [38].

\section{Sleep}

Three studies explored whether FCC providers were meeting sleep recommendations (7 or more hours of sleep per night); between 43.4 and $56.7 \%$ were regularly meeting these goals $[24,32]$.

\section{Smoking}

A small proportion of providers reported being current smokers; from $15.6 \%$ of CCC staff [23] to just 7.5\% of FCC providers [24].

\section{Chronic disease status}

Three studies assessed diabetes prevalence and found similar rates $(10.6 \%$ for FCC, $10.4 \%$ for FCC, $11.9 \%$ for HS) [24,33] compared to just $7.8 \%$ of a comparable national sample [33]. Rates of diagnosed high blood pressure included 22.3\% of HS staff and $36 \%$ of FCC providers [24, 33]. One study of HS staff found higher rates of four additional chronic diseases and conditions (severe headache/migraine, lower back pain, obesity and asthma) as compared to a similar national sample [33].

\section{Mental health}

In total, we found 21 studies that included measurement of mental health including depression (15 studies), stress (8 studies), and mindfulness (3 studies).

\section{Depression}

Fifteen studies explored depression levels of ECE providers; from two samples of FCC, approximately $23 \%$ reported a depressive disorder or diagnosis [24]. Among the five analyses of HS staff, one study found an average Center for Epidemiologic Studies-Depression (Scale) (CES-D) of 10.8 (at or above 16 is considered screening positive for depression) [12]; another found $35 \%$ of respondents with at least moderate depression at two time points during the year [18]; and Ling found that $31 \%$ of HS teachers were experiencing depressive symptoms [22]. In two analyses from the Pennsylvania Head Start Survey [33, 34], approximately $24 \%$ of respondents had a CES-D score at or above 16 . This contrasts with only $17.6 \%$ of a national comparison sample with similar demographics. The eight studies that included CCC staff generally found lower rates of 
depressive symptoms; fewer than $19 \%$ of respondents in one study of CCC staff scored above 16 on the CES-D [35] and only $8.9 \%$ of respondents in another study had clinically significant depression [26]. Two analyses of data from CCC providers in North Carolina found higher rates of depression (34.9-36\% with a CES-D at or above 16), compared to the national average of $12.3 \%$ of women ages $40-59$ [9, 23].

\section{Stress}

While only one of the eight studies that explored stress levels of providers included prevalence data on high stress, several explored the impact that stress levels have on performance. One study of 39 providers (CCC staff and FCC providers) found that higher levels of provider stress were associated with lower child engagement in the classroom [25]. Another study found that stress levels were associated with a greater intention for teachers to leave rather than stay in their positions [15]. In a survey of FCC providers conducted by Tovar and colleagues (2017), 62\% of respondents had a high stress score on the Perceived Stress Scale [32].

\section{Mindfulness}

Three studies measured mindfulness traits among ECE providers, each with a different measure (CAMS-R, FFMQ, MAAS), which makes comparisons across samples difficult.

\section{Interventions}

Following the literature and practice searches, seven published and four unpublished programs were identified. Details on the audience, target behaviors/outcomes, activities/components, and evaluation results (if available) are included in Table 3.

\section{Audience}

The majority of the programs were delivered to center-based teachers and staff, with only one developed specifically for family child care providers $[44,46]$. Others focused on Head Start staff $[39,42]$ or a broader audience of providers including FCC (33, Building Well-Being Resilient).

\section{Target behaviors and program components}

All but one program included nutrition/healthy eating components; most included physical activity and five included stress or other mental health-related targets. The majority of the published interventions were larger, multi-component interventions that included some staff wellness component (as opposed to a stand-alone staff intervention). Most were also conducted over a long period of time ranging from 6 to 12 months with multiple pedagogical techniques (e.g., workshops, print materials, individual or group coaching). Only one identified program (YMCA child care) described ongoing efforts that are always available to employees. All others represented one-time interventions, with the majority sponsored by outside organizations and/or researchers working in conjunction with providers. 
Table 3 Summary of wellness programs targeting the early care and education workforce identified in a scoping review

\begin{tabular}{l} 
Source \\
\hline Published literature \\
Esquivel et al., \\
Children's Healthy \\
Living Program for \\
Remote Underserved \\
Minority Populations \\
in the Pacific \\
Region [39]
\end{tabular}

Messiah et al., Healthy Caregivers - Healthy Children (HC2) [40]
Target population Targ outcomes

\section{HS teachers in} Hawaii

CCC in Florida (1)

cccin Florida

\begin{abstract}
Arandia et al., Caring and Reaching for Health's Healthy LIfestyles Intervention
\end{abstract} (CARE) [8]

$\begin{array}{ll}\text { CCC in North } & \text { Nutrition and } \\ \text { Carolina } & \text { physical activity }\end{array}$

\section{Gosliner et al. [41]}

Physical activity
California. $98 \%$ of participants were female. 91\% were aged 25 to 64

years. $49 \%$ were white, 24\% Asian or Pacific Islander, 17\% African American, 13\% Hispanic/Latino, and $6 \%$ other. $52 \%$ of participants had attended some College education,
Teacher health status and health behaviors; knowledge, misconceptions, beliefs and priorities on nutrition and childhood obesity preventions

Nutrition and
physical activity
(measured via accelerometry); secondary outcomes include other health behaviors (e.g., diet, weight, smoking),

physical health indicators (e.g., BMI, blood pressure, fitness tests)
Staff wellness classes as part of a larger,

7- month long intervention targeting policy and classroomlevel changes. Monthly classes focused on benefits of physical activity (PA), stretching and PA ideas at work; benefits of healthy eating and food tasting, and; stress management.

Using a train the trainer approach, policy changes regarding nutrition, physical activity and screen time were pursued with participating CCCs. Teachers and parents also received six monthly workshops to support their role as healthy role models for children.

Multi-component, theory-based intervention includes a kick-off event and educational workshop and three 8-week campaigns (6 months total duration). Each campaign focused on a different PA-related topic and included print materials, goal setting and selfmonitoring, tailored feedback, email and text prompts and coaching for CCC directors.

Wellness program added to existing intervention focused on obesity-related policy change in

CCCs. Activities included day-long kick-off training, monthly newsletters and paycheck insert, and a staff walking program. (if available)

Impact on HS teacher health not provided

Not available
Pilot results suggested that the intervention resulted in significant decreases in provider BMI and smoking along with increases in physical activity and fruit/ vegetable intake
Compared to a control group, intervention participants reported sugar swe
beverage consumption; significantly higher ease of engaging parents in discussion of child's eating and comfort talking to parents about 
Table 3 Summary of wellness programs targeting the early care and education workforce identified in a scoping review (Continued)

\begin{tabular}{|c|c|c|c|c|}
\hline Source & Target population & $\begin{array}{l}\text { Target behavior(s)/ } \\
\text { outcomes }\end{array}$ & Activities/components & $\begin{array}{l}\text { Evaluation results } \\
\text { (if available) }\end{array}$ \\
\hline & $\begin{array}{l}21 \% \text { had received } \\
\text { an associate } \\
\text { degree or } 16 \% \\
\text { had a bachelor's } \\
\text { degree. }\end{array}$ & & & $\begin{array}{l}\text { child's PA. Other } \\
\text { differences were } \\
\text { not significant. }\end{array}$ \\
\hline $\begin{array}{l}\text { Herman et al., Eat } \\
\text { Healthy, Stay } \\
\text { Active! [42] }\end{array}$ & $\begin{array}{l}\text { HS teachers in } \\
\text { Pennsylvania, } \\
\text { Texas, Arizona, } \\
\text { Rhode Island and } \\
\text { New York. 96\% of } \\
\text { participants were } \\
\text { female. } 56 \% \text { were } \\
\text { white, } 1.4 \% \text { Asian } \\
\text { or Pacific Islander, } \\
14.3 \% \text { African } \\
\text { American, 17.5\% } \\
\text { Hispanic/Latino, } \\
3.6 \% \text { Native } \\
\text { American, and } \\
2.4 \% \text { other. } 15 \% \\
\text { had a high school } \\
\text { diploma or GED, } \\
17 \% \text { had an } \\
\text { associate's degree, } \\
\text { and } 65 \% \text { had a } \\
\text { bachelor's degree. } \\
60.5 \% \text { of } \\
\text { participants were } \\
\text { married, } 91 \% \\
\text { worked part-time, } \\
\text { and } 4 \% \text { worked } \\
\text { full-time }\end{array}$ & $\begin{array}{l}\text { Nutrition and physical } \\
\text { activity; weight } \\
\text { change, knowledge } \\
\text { and behavior }\end{array}$ & $\begin{array}{l}\text { Six-month } \\
\text { multi-component } \\
\text { intervention targeting } \\
\text { nutrition and PA } \\
\text { among children, } \\
\text { teachers and parents. } \\
\text { Staff received } 1 \text { day } \\
\text { of training on } \\
\text { intervention } \\
\text { components and } \\
\text { then delivered } \\
\text { workshops to } \\
\text { parents and } \\
\text { children. }\end{array}$ & $\begin{array}{l}\text { Significant } \\
\text { decrease in staff } \\
\text { BMI, significant } \\
\text { increase in } \\
\text { knowledge, diet } \\
\text { and physical } \\
\text { activity. }\end{array}$ \\
\hline $\begin{array}{l}\text { Jones, Teacher be } \\
\text { well: Mindfulness } \\
\text { based stress } \\
\text { reduction [43] }\end{array}$ & $\begin{array}{l}\text { CCC on military } \\
\text { base in San Diego, } \\
\text { California }\end{array}$ & $\begin{array}{l}\text { Mindfulness, } \\
\text { workplace stress }\end{array}$ & $\begin{array}{l}\text { Two-hour mindfulness } \\
\text { workshop that } \\
\text { included lecture, } \\
\text { discussion, exercises } \\
\text { coupled with take- } \\
\text { home resources. } \\
\text { Printed materials } \\
\text { supporting the } \\
\text { content were } \\
\text { available in the } \\
\text { break room. }\end{array}$ & $\begin{array}{l}\text { No significant } \\
\text { impact on } \\
\text { mindfulness or } \\
\text { workplace } \\
\text { stress among } \\
\text { participants } \\
(n=27) \text {. Process } \\
\text { evaluation } \\
\text { showed that } \\
\text { the program } \\
\text { was feasible and } \\
\text { participants were } \\
\text { satisfied with the } \\
\text { program. }\end{array}$ \\
\hline $\begin{array}{l}\text { Ostbye et al., Keys } \\
\text { to Healthy Child } \\
\text { Care [44] }\end{array}$ & $\begin{array}{l}\text { FCC providers in } \\
\text { North Carolina. } \\
57.5 \% \text { of providers } \\
\text { were African } \\
\text { American, } 40 \% \\
\text { were White, and } \\
2.5 \% \text { were Asian. } \\
\text { Mean age of } \\
\text { providers was } \\
46.2 \text { years. }\end{array}$ & $\begin{array}{l}\text { Physical activity, diet } \\
\text { quality, height and } \\
\text { weight; and FCC } \\
\text { environment }\end{array}$ & $\begin{array}{l}\text { Nine-month, } \\
\text { three component } \\
\text { intervention guided } \\
\text { by Social Ecological } \\
\text { Model and Social } \\
\text { Cognitive Theory. } \\
\text { Three months each } \\
\text { are spent on: Healthy } \\
\text { You, Healthy Home } \\
\text { and Healthy Business } \\
\text { concepts. A health } \\
\text { behavior coach is } \\
\text { paired to each } \\
\text { participant and } \\
\text { provides one group } \\
\text { workshop, one in- } \\
\text { person visit to the } \\
\text { FCC home, three }\end{array}$ & $\begin{array}{l}\text { No results } \\
\text { available }\end{array}$ \\
\hline
\end{tabular}


Table 3 Summary of wellness programs targeting the early care and education workforce identified in a scoping review (Continued)

\begin{tabular}{|c|c|c|c|c|}
\hline Source & Target population & $\begin{array}{l}\text { Target behavior(s)/ } \\
\text { outcomes }\end{array}$ & Activities/components & $\begin{array}{l}\text { Evaluation results } \\
\text { (if available) } \\
\end{array}$ \\
\hline & & & $\begin{array}{l}\text { tailored phone calls } \\
\text { and a written toolkit. }\end{array}$ & \\
\hline \multicolumn{5}{|l|}{ Unpublished } \\
\hline $\begin{array}{l}\text { Be Well, Care Well } \\
\text { (Medical University } \\
\text { of South Carolina, } \\
\text { Boeing Center for } \\
\text { Children's Wellness) }\end{array}$ & $\begin{array}{l}\text { CCC providers in } \\
\text { targeted regions } \\
\text { of South Carolina }\end{array}$ & $\begin{array}{l}\text { Overall wellness, } \\
\text { resilience, physical } \\
\text { activity, healthy diet, } \\
\text { stress, job satisfaction }\end{array}$ & $\begin{array}{l}\text { Well-Being Coaches } \\
\text { work with center-level } \\
\text { committees } \\
\text { composed of three or } \\
\text { more members (one } \\
\text { administrator, one or } \\
\text { more teachers, one or } \\
\text { more parents) to } \\
\text { identify well-being } \\
\text { goals. Through } \\
\text { weekly, on-site visits } \\
\text { the coaches work } \\
\text { with committee to } \\
\text { achieve selected well- } \\
\text { being goals, provide } \\
\text { support and } \\
\text { incentives and } \\
\text { connections to } \\
\text { local resources. }\end{array}$ & Not available. \\
\hline $\begin{array}{l}\text { Create Healthy } \\
\text { Futures (Penn State } \\
\text { Extension Better } \\
\text { Kid Care in } \\
\text { collaboration with } \\
\text { UTHealth School of } \\
\text { Public Health) [45] }\end{array}$ & $\begin{array}{l}\text { ECE providers } \\
\text { across multiple } \\
\text { settings in } \\
\text { Cleveland, } \\
\text { Ohio. } 97.3 \% \text { of } \\
\text { participants were } \\
\text { female. } 41.5 \% \\
\text { were African } \\
\text { American. Mean } \\
\text { age was } 43.5 \text { years }\end{array}$ & $\begin{array}{l}\text { Improve consumption } \\
\text { of healthy foods, } \\
\text { raise awareness } \\
\text { of the nutrition } \\
\text { environment, support } \\
\text { ECE professionals as } \\
\text { role models for } \\
\text { children and families }\end{array}$ & $\begin{array}{l}\text { Four-hour, self- } \\
\text { paced, online } \\
\text { program developed } \\
\text { using Social Cognitive } \\
\text { Theory and the Social } \\
\text { Ecological Model. } \\
\text { Content includes } \\
\text { videos, reflection } \\
\text { activities, } \\
\text { downloadable } \\
\text { handouts and } \\
\text { action planning. } \\
\text { Topics covered } \\
\text { include basic nutrition } \\
\text { information, healthy } \\
\text { eating strategies, food } \\
\text { environment and } \\
\text { food culture reform. } \\
\text { Participants also } \\
\text { receive } 6 \text { weeks of } \\
\text { peer coaching } \\
\text { sessions to support } \\
\text { healthy behavior } \\
\text { change. }\end{array}$ & $\begin{array}{l}\text { One pilot study } \\
\text { conducted } \\
\text { with } 111 \text { ECE } \\
\text { professionals } \\
\text { from four facilities. } \\
\text { Participants } \\
\text { showed increase } \\
\text { in nutrition } \\
\text { knowledge, } \\
\text { decrease in } \\
\text { perceived barriers } \\
\text { to promote } \\
\text { healthy nutrition } \\
\text { in the classroom, } \\
\text { and improved } \\
\text { wellness support } \\
\text { at their workplace. } \\
\text { Process evaluation } \\
\text { results found the } \\
\text { program to be } \\
\text { helpful, } \\
\text { acceptable } \\
\text { and feasible. } \\
\text { Additional study } \\
\text { on the effect of } \\
\text { the program is } \\
\text { underway with a } \\
\text { larger sample of } \\
\text { Head Start } \\
\text { professionals. }\end{array}$ \\
\hline $\begin{array}{l}\text { Building Well-Being. } \\
\text { Resilient Nourished } \\
\text { Active. (Spokane } \\
\text { Washington } \\
\text { Regional Health } \\
\text { District) }\end{array}$ & $\begin{array}{l}\text { Early learning staff } \\
\text { (including cooks) } \\
\text { and directors in } \\
\text { Spokane, } \\
\text { Washington }\end{array}$ & $\begin{array}{l}\text { Social emotional } \\
\text { well-being and } \\
\text { self-regulation; } \\
\text { healthy nutrition } \\
\text { and menus; } \\
\text { promoting active } \\
\text { play among children }\end{array}$ & $\begin{array}{l}\text { Year-long program } \\
\text { focused on emotional } \\
\text { and physical well- } \\
\text { being of both staff } \\
\text { and children. One-on- } \\
\text { one coaching, } \\
\text { monthly online } \\
\text { webinars, teaching } \\
\text { tools provided to } \\
\text { participants and } \\
\text { in-person interactive } \\
\text { trainings on healthy }\end{array}$ & $\begin{array}{l}\text { Pilot underway } \\
\text { with six centers } \\
\text { (125 teachers). } \\
\text { Evaluation will } \\
\text { measure impact } \\
\text { on child- and } \\
\text { adult-level } \\
\text { outcomes } \\
\text { including } \\
\text { proportion } \\
\text { modeling deep } \\
\text { breathing }\end{array}$ \\
\hline
\end{tabular}


Table 3 Summary of wellness programs targeting the early care and education workforce identified in a scoping review (Continued)

\begin{tabular}{|c|c|c|c|c|}
\hline Source & Target population & $\begin{array}{l}\text { Target behavior(s)/ } \\
\text { outcomes }\end{array}$ & Activities/components & $\begin{array}{l}\text { Evaluation results } \\
\text { (if available) }\end{array}$ \\
\hline & & & $\begin{array}{l}\text { eating and active play } \\
\text { for staff with an } \\
\text { emphasis on how } \\
\text { nutrition and physical } \\
\text { activity influence } \\
\text { mood, behavior } \\
\text { and health of staff. }\end{array}$ & $\begin{array}{l}\text { techniques when } \\
\text { addressing } \\
\text { conflict and } \\
\text { teacher } \\
\text { engagement } \\
\text { in physical } \\
\text { activity with } \\
\text { children. }\end{array}$ \\
\hline $\begin{array}{l}\text { YMCA child care } \\
\text { facilities and camp } \\
\text { (Greater Wichita } \\
\text { Kansas YMCA) }\end{array}$ & $\begin{array}{l}\text { Staff of YMCA } \\
\text { child care facilities } \\
\text { and camps in } \\
\text { Greater Wichita, } \\
\text { Kansas }\end{array}$ & $\begin{array}{l}\text { General wellness, } \\
\text { healthy eating, } \\
\text { physical activity and } \\
\text { mind-body balance }\end{array}$ & $\begin{array}{l}\text { Staff receive free } \\
\text { YMCA memberships, } \\
\text { annual biometric } \\
\text { screenings, voucher } \\
\text { for preventive health } \\
\text { visits, staff games, and } \\
\text { quarterly health } \\
\text { challenges. Staff also } \\
\text { have access to } \\
\text { monthly webinars } \\
\text { focusing on wellness } \\
\text { topics. }\end{array}$ & Not available. \\
\hline
\end{tabular}

\section{Evaluation result}

Limited evidence on the effectiveness of these interventions is available. Among the published interventions, only four included participant-level impact data. The CARE Intervention has shown preliminary evidence of impact; a pilot study showed positive impact on BMI, physical activity, fruit and vegetable intake, and smoking [8]. Another intervention, offered over 9 months as part of a larger intervention targeting centerbased providers in California, showed positive impact on only sugar sweetened beverage consumption [41]. The Eat Healthy, Stay Active! program has been shown to positively impact provider BMI, diet, physical activity, and health-related knowledge [42]. A one-time mindfulness workshop did not show significant impact on provider mindfulness or workplace stress [43]. Among the unpublished programs, only one has evaluation results available. The Create Healthy Futures program, a 4-hour online program, showed improvements in nutrition knowledge and perceived barriers to promoting wellness in the classroom [45].

\section{Discussion}

This scoping review provides a well-rounded picture of the health status of the ECE workforce in the USA along with description of interventions recently implemented to improve health in this population. From the health status literature, it is clear that many ECE providers struggle with chronic disease risk behaviors (e.g., healthy eating, sedentary time) and mental health challenges (e.g., stress and depression). These challenges persisted across setting (e.g., HS versus CCC; teachers versus directors). This is likely exacerbated by the low socioeconomic status among a majority of ECE providers, as well as lack of access to health insurance through their employers [1]. Given that many child care centers and homes cannot afford to provide health insurance, introducing workforce wellness programs may be an affordable work-around to addressing chronic disease risk behaviors and mental health challenges. Specific recommendations on health behavior targets likely vary depending on the ECE type (e.g., FCC versus HS) 
and the local context; however, it is clear that there is room for improvement across the board for physical activity and diet. Many providers in the included studies were overweight or obese, raising their chronic disease risk.

For physical activity, three studies found that ECE providers spend between 4 and $8.6 \mathrm{~h} /$ day in sedentary activity levels, which have been shown to be associated with obesity and certain cancers, independent of physical activity levels [47, 48]. Thus, interventions targeting sedentary time may be especially warranted in this population.

Insight can also be drawn from research done on ECE providers in other countries, as well, as workplace stress is a common factor for child care providers in many countries. For example, Corr et al. looked into the relationship between Australian family child care educators' mental health and working conditions, finding that social support was associated with higher mental well-being [49]. Similarly, Nislin et al. found that teamwork was critical to supporting the well-being of ECE providers in Finland [50]. Both of these studies were conducted in countries where there is significantly more government financial support for ECE providers (in Australia, for example, over 70\% of ECE providers said their income was "enough" or "more than enough" to meet needs) [49], as well as nearly universal health care access, which eliminates some of the socioeconomic stresses that American ECE providers face.

The interventions and programs included in our review provide a wide range of options for future efforts. Many were embedded in larger, facility-wide programs targeting obesity prevention in adults and children. Research shows that Whole Systems Approaches are most likely to have a significant impact on complex public health challenges including obesity [51]. Most were conducted over 6 months or more, illustrating that impact on chronic disease and mental health outcomes requires a significant investment of time and support. Given the diversity within the ECE workforce, it is also likely that different intervention approaches will need to be used for different audiences. For example, interventions originally developed for center-based staff may not be appropriate for family child care providers who have different access to colleagues (e.g., social support) and administrative supports to facilitate wellness programming.

There have been calls in the literature for an increase in practice-based evidence (PBE) or studies that combine the rigor of the scientific process with the realities of implementation in the real world [52]. Researchers interested in this approach can use the list of interventions provided here as a jumping off point to develop collaborative research projects to assess the implementation and impact of these interventions on the ECE workforce. Additional research should be done to determine the extent to which these programs align with best practices in worksite health promotion developed by the CDC [53].

\section{Limitations}

Many of the descriptive studies did not include a comparison group of individuals with similar demographics but different occupations. Such a group would improve understanding of whether the health status of the ECE workforce is different from others with similar demographic characteristics, especially age, education level, and income. Our programs only included one facility-level wellness intervention (YMCA child care), though ECE professionals connected to larger employers, such as corporations or 
universities, are likely have access to employee wellness programs. A recent national survey found that nearly $50 \%$ of workplaces in the USA with at least 10 employees offer some sort of employee wellness programming [54]. While none of those programs responded to our call for programs, the authors are aware that these initiatives exist across the country despite their relative absence from our review.

\section{Conclusions}

The results of this scoping review suggest that additional research into the health status of the ECE workforce is needed to properly categorize chronic disease risk across the diversity of the workforce. The limited body of evidence available for review paints a picture of a workforce in need of health promotion intervention to address high levels of mental and physical health challenges, some above and beyond peers with comparable demographic characteristics. Several promising interventions were identified from both the published and unpublished literature; these interventions should be further implemented and evaluated to assess their impact on the workforce.

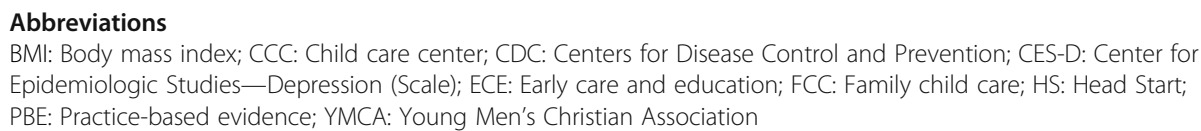

\section{Acknowledgements}

Not applicable

\section{Authors' contributions}

LL conceived of the study, analyzed the data, drafted portions of the manuscript, and reviewed and approved the final version. KW drafted portions of the manuscript and reviewed and approved the final version. JRM drafted portions of the manuscript and reviewed and approved the final version. MCM conducted literature searches, analyzed the data, and reviewed and approved the final version.

Funding

This project did not receive any external funding.

Availability of data and materials

Data sharing is not applicable to this article as no datasets were generated or analyzed during the current study.

Ethics approval and consent to participate

Not applicable. This project did not include human subjects research and was not subject to Institutional Review Board review.

\section{Consent for publication}

Not applicable

Competing interests

The authors declare that they have no competing interests.

\section{Author details}

${ }^{1}$ University of Delaware, College of Health Sciences, Newark, DE 19716, USA. ${ }^{2}$ Child Care Aware of America, 1515 N. Courthouse Rd-3rd Floor, Arlington, VA 22201, USA.

Received: 11 June 2019 Accepted: 17 December 2019

Published online: 08 January 2020

References

1. Whitebook M, McLean C, Austin LJE, Edwards B. Early childhood workforce index - 2018, vol. 4. Berkeley: Center for the Study of Child Care Employment, University of California, Berkeley; 2018.

2. Scott K, Looby AA, Hipp JS, Frost N. Applying an equity lens to the child care setting. J Law Med Ethics. 2017;45(1_suppl):77-81.

3. Gould E. Child care workers aren't paid enough to make ends meet. Washington: Economic Policy Institute; 2015.

4. Adler NE, Stewart J. Health disparities across the lifespan: meaning, methods, and mechanisms. Ann N Y Acad Sci. 2010; 1186(1):5-23.

5. Adler N, Stewart J, Cohen S, et al. Reaching for a healthier life: facts on socioeconomic status and health in the United States. San Francisco: The John D. and Catherine T MacArthur Foundation Research Network on Socioeconomic Status and Health; 2007. Available at http://www.macses.ucsf.edu. 
6. Centers for Disease Control and Prevention. CDC Health Disparities and Inequalities Report - United States, 2013. MMWR. 2013;62(Suppl3):1-2.

7. Stiehl E, Shivaprakash N, Thatcher E. Worksite health promotion for low-wage workers: a scoping literature review. Am J Health Promot. 2017;32(2):359-73. https://doi.org/10.1177/0890117117728607.

8. Arandia G, Vaughn AE, Bateman LA, Ward DS, Linnan LA. Development of a workplace intervention for child care staff: Caring and Reaching for Health's (CARE) healthy lifestyles intervention. Health Promot Pract. 2018. https://doi.org/10. $1177 / 1524839918786214$

9. Ward DS, Vaughn $A E$, Hales $D$, et al. Workplace health and safety intervention for child care staff: rationale, design, and baseline results from the CARE cluster randomized control trial. Contemp Clin Trials. 2018;68:116-26. https://doi.org/10. 1016/j.cct.2018.02.018.

10. Rumrill PD, Fitzgerald SM, Merchant WR. Using scoping literature reviews as a means of understanding and interpreting existing literature. Work. 2010;35(3):399-404. https://doi.org/10.3233/WOR-2010-0998.

11. Arksey H, O'Malley L. Scoping studies: towards a methodological framework. Int I Soc Res Methodol. 2005;8(1):19-32. https://doi.org/10.1080/1364557032000119616.

12. Becker BD, Gallagher KC, Whitaker RC. Teachers' dispositional mindfulness and the quality of their relationships with children in Head Start classrooms. J Sch Psych. 2017;65:40-53. https://doi.org/10.1016/j.jsp.2017.06.004.

13. Denham SA, Bassett HH, Miller SL. Early childhood teachers' socialization of emotion: contextual and individual contributors. Child Youth Care Forum. 2017;46(6):805-24.

14. Figueroa R, Wiley A. Factors associated with time provided to children for physical activity in family child care: a crosssectional study. SpringerPlus. 2016;5(1):1730.

15. Grant AA, Jeon L, Buettner CK. Relating early childhood teachers' working conditions and well-being to their turnover intentions. Educ Psychol. 2016. https://doi.org/10.1080/01443410.2018.1543856.

16. Halloran KM, Gorman K, Fallon M, Tovar A. Nutrition knowledge, attitudes, and fruit and vegetable intake as predictors of Head Start teachers' classroom mealtime behaviors. J Nutr Educ Behav. 2018;50:340-8. https://doi.org/10.1016/j.jneb.2017.10.015.

17. Hibbs-Ship SK, Milholland M, Bellows L. Barriers and facilitators to healthy eating and activity in head start staff: an opportunity for worksite wellness. Am J Health Educ. 2015;46(6):347-50. https://doi.org/10.1080/19325037.2015.1077488.

18. Hindman AH, Bustamante AS. Teacher depression as a dynamic variable: exploring the nature and predictors of change over the head start year. J Appl Dev Psychol. 2019;61:43-55. https://doi.org/10.1016/j.appdev.2018.09.004.

19. Jennings PA. Early childhood teachers' well-being, mindfulness, and self-compassion in relation to classroom quality and attitudes towards challenging students. Mindfulness. 2015;6(4):732-43. https://doi.org/10.1007/s12671-014-0312-4.

20. Jeon L, Buettner CK, Grant AA. Early childhood teachers' psychological well-being: exploring potential predictors of depression, stress, and emotional exhaustion. Early Educ Dev. 2018;29(1):53-69.

21. Jeon HJ, Kwon KA, Walsh B, Burnham MM, Choi YJ. Relations of early childhood education teachers' depressive symptoms, job-related stress, and professional motivation to beliefs about children and teaching practices. Early Educ Dev. 2019;30(1):131-44

22. Ling J. Behavioral and psychosocial characteristics among Head Start childcare providers. J Sch Nurs. 2018;34(6):435-41. https://doi.org/10.1177/1059840517725791.

23. Linnan L, Arandia G, Bateman LA, Vaughn A, Smith N, Ward D. The health and working conditions of women employed in child care. Int J of Environ Res Public Health. 2017;14:283. https://doi.org/10.3390/ijerph14030283.

24. Magerko KA. Healthy hearts in family child care: what is the current state of provider health? [dissertation]: University of Illinois; 2016

25. Ota CL, Baumgartner JL, Berghout Austin AM. Provider stress and children's active engagement. J Res Child Ed. 2013; 27(1):61-73. https://doi.org/10.1080/02568543.2012.739588.

26. Roberts AM, Gallagher KC, Daro AM, Iruka IU, Sarver SL. Workforce well-being: personal and workplace contributions to early educators' depression across settings. J Appl Dev Psychol. 2017. https://doi.org/10.1016/j.appdev.2017.09.007.

27. Sandilos LE, Cycyk LM, Scheffner Hammer C, Sawyer BE, López L, Blair C. Depression, control, and climate: an examination of factors impacting teaching quality in preschool classrooms. Early Educ Dev. 2015;26(8):1111-27. https:// doi.org/10.1080/10409289.2015.1027624.

28. Sharma S, Dortch KS, Byrd-Williams C, Truxillio JB, Rahman GA, Bonsu P, Hoelscher D. Nutrition-related knowledge, attitudes, and dietary behaviors among head start teachers in Texas: a cross-sectional study. J Acad Nutr Diet. 2013; 113(4):558-62.

29. Snyder K, Hill M. Wellbeing begins with employees: exploring associations of physical health in a Head Start organization [Master's thesis]: Wright State University; 2018.

30. Song WO, Song S, Nieves V, Gonzalez A, Crockett ET. Nutritional health attitudes and behaviors and their associations with the risk of overweight/obesity among child care providers in Michigan Migrant and Seasonal Head Start centers. BMC Public Health. 2016;16(1):648.

31. Swindle TM, Ward WL, Bokony P, Whiteside-Mansell L. A cross-sectional study of early childhood educators' childhood and current food insecurity and dietary intake. J Hunger Environ Nutr. 2018;13(1):40-54.

32. Tovar A, Vaughn AE, Grummon A, et al. Family child care home providers as role models for children: cause for concern? Prev Med Rep. 2017;5:308-13. https://doi.org/10.1016/.jpmedr.2016.11.010.

33. Whitaker RC, Becker BD, Herman AN, Gooze RA. The physical and mental health of Head Start staff: The Pennsylvania Head Start Staff Wellness Survey, 2012. Prev Chronic Dis. 2013;10:130171. https://doi.org/10.5888/pcd10.130171.

34. Whitaker RC, Dearth-Wesley T, Gooze RA. Workplace stress and the quality of teacher-children relationships in Head Start. Early Child Res Q. 2015:30:57-69. https://doi.org/10.1016/..ecresq.2014.08.008.

35. Witherell SL. Work-related stress and mental health of child care center workers [dissertation]. Detroit: Wayne State University; 2013.

36. Faulkner M, Gerstenblatt $P$, Lee A, et al. Childcare providers: work stress and personal well-being. J Early Child Res. 2016; 14(3):280-93. https://doi.org/10.1177/1476718X14552871.

37. Lindsay AC, Greaney ML, Wallington SF, et al. Easier said than done: a qualitative study conducted in the USA exploring Latino family child care home providers as role models for healthy eating and physical activity behaviours. BMJ Open. 2017;7:1-7. https://doi.org/10.1136/bmjopen-2017-018219. 
38. Centers for Disease Control and Prevention. Selected health conditions and risk factors, by age: United States, selected years 1988-1994 through 2015-2016. 2017. https://www.cdc.gov/nchs/data/hus/2017/053.pdf. Accessed 30 May 2019.

39. Esquivel MK, Nigg CR, Fialkowski MK, Braun KL, Li F, Novotny R. Influence of teachers' personal health behaviors on operationalizing obesity prevention policy in head start preschools: a project of the Children's Healthy Living Program (CHL). J Nutr Educ Behav. 2016;48:318-25. https://doi.org/10.1016/j.jneb.2016.02.007.

40. Messiah SE, Lebron C, Moise R, Mathew MS, Sardinas K, Chang C, Palenzuela J, Walsh J, Shelnutt KP, Spector R, Altare F. Healthy caregivers-healthy children ( $\mathrm{HC2}$ ) phase 2 : integrating culturally sensitive childhood obesity prevention strategies into childcare center policies. Contemp Clin Trials. 2017;53:60-7.

41. Gosliner WA, James P, Yancey AK, Ritchie L, Studer N, Crawford PB. Impact of a worksite wellness program on the nutrition and physical activity environment of child care centers. Am J Health Promot. 2010;24(3):186-9. https://doi.org/ 10.4278/ajhp.08022719.

42. Herman A, Nelson BB, Teutsch C, Chung PJ. "Eat Healthy, Stay Active!": A coordinated intervention to improve nutrition and physical activity among Head Start parents, staff, and children. Am J Health Promot. 2012;27(1):27-36. https://doi. org/10.4278/ajhp.110412-QUAN-157.

43. Jones KJ. Promoting stress reduction using mindfulness for educators in a military based child development center [master's thesis]: San Diego State University; 2018.

44. Ostbye T, Mann CM, Vaughn AE, et al. The keys to healthy family child care homes intervention: study design and rationale. Contemp Clin Trials. 2015;40:81-9. https://doi.org/10.1016/j.cct.2014.11.003.

45. UTHealth School of Public Health, Michael \& Susan Dell Center for Healthy Living, Penn State Extension Better Kid Care Program. Create Healthy Futures: an online wellness program for ECE Professionals. 2018.

46. Mann CM, Ward DS, Vaughn, et al. Application of the intervention mapping protocol to develop keys, a family child care home intervention to prevent early childhood obesity. BMC Public Health 2015;15:1-13. https://doi.org/10.1186/ s12889-015-2573-9.

47. Shen D, Mao W, Liu T, et al. Sedentary behavior and incident cancer: a meta-analysis of prospective studies. PLoS One. 2014;9(8):e105709. https://doi.org/10.1371/journal.pone.0105709.

48. Thorp AA, Owen N, Neuhaus M, Dunstan DW. Sedentary behaviors and subsequent health outcomes in adults: a systematic review of longitudinal studies, 1996-2011. Am J Prev Med. 2011;41(2):207-15. https://doi.org/10.1016/j. amepre.2011.05.004.

49. Corr L, Lamontagne AD, Cook K, Waters E, Davis E. Associations between Australian early childhood educators' mental health and working conditions: a cross-sectional study. Australas J Early Childhood. 2015;40(3):69-78.

50. Nislin MA, Sajaniemi NK, Sims M, Suhonen E, Maldonado EF, Montero AH, Hyttinen S. Pedagogical work, stress regulation and work-related well-being among early childhood professionals in integrated special day-care groups, European Journal of Special Needs Education; 2015.

51. Bagnall AM, Radley D, Jones R, et al. Whole systems approaches to obesity and other complex public health challenges: a systematic review. BMC Public Health. 2019;19(1):8. https://doi.org/10.1186/s12889-018-6274-z.

52. Ammerman A, Smith TW, Calancie L. Practice-based evidence in public health: improving reach, relevance, and results. Annu Rev Public Health. 2014;35:47-63. https://doi.org/10.1146/annurev-publhealth-032013-182458.

53. Gutermuth LK, Hager ER, Pollack PK. Using the CDC's worksite health scorecard as a framework to examine worksite health promotion and physical activity. Prev Chronic Dis. 2018;15:E84. https://doi.org/10.5888/pcd15.170463.

54. Linnan LA, Cluff L, Lang JE, Penne M, Leff MS. Results of the Workplace Health in America Survey. Am J Health Promot. 2019. https://doi.org/10.1177/0890117119842047.

\section{Publisher's Note}

Springer Nature remains neutral with regard to jurisdictional claims in published maps and institutional affiliations.

Ready to submit your research? Choose BMC and benefit from:

- fast, convenient online submission

- thorough peer review by experienced researchers in your field

- rapid publication on acceptance

- support for research data, including large and complex data types

- gold Open Access which fosters wider collaboration and increased citations

- maximum visibility for your research: over $100 \mathrm{M}$ website views per year

At BMC, research is always in progress.

Learn more biomedcentral.com/submissions 